\title{
Ewolucja niektórych elementów stereotypu psa w polszczyźnie
}

Człowiek widzi świat przez pryzmat języka, za którego pomocą opisuje i interpretuje rzeczywistość. Wielokrotnie jest to widzenie znacznie uproszczone, pozbawione dociekliwej analizy, próby rzetelnego zaobserwowania i sprawiedliwego ocenienia zjawisk otaczającego świata. Język dysponuje takimi środkami, które to uproszczenie znacznie ułatwiają. Tymi elementami są stereotypy językowe. Utrwalone wyobrażenia o obiekcie, połączone na stałe z ocenami, systemem wartości i wzorami zachowań, mocno zakorzenione w świadomości i języku niełatwo dają się zweryfikować. Potoczne, stereotypowe myślenie o czymś czy stereotypowa ocena czegoś zawsze są rozumiane jako krzywdzące, bezrefleksyjne. Za cechy konstytutywne stereotypu uważa się niezmienność, stałość, długotrwałość, nieweryfikowalność, odporność na zmiany, uporczywość trwania, nieelastyczność i konwencjonalność (Panasiuk 1998, 84).

Przedmiotem zainteresowania w tym artykule jest stereotyp psa w polszczyźnie czy raczej jego niektóre elementy. Wydaje się on bardzo mocno potwierdzać cechy niezmienności, stałości, uporczywości trwania. Chodzi tu o cechy najsilniej utrwalone w świadomości użytkownika języka, te, które określa się jako ,jądro stereotypu”, czyli wyobrażenie najbardziej typowego reprezentanta grupy obiektów (Bartmiński, Panasiuk 1993, 374).

Wiadomo, że stereotyp psa uwzględnia jedynie fragmenty związanej z nim rzeczywistości, te, których utrwalenie łączy się ze zbiorowym doświadczeniem społeczeństwa i z powszechnie przyjętym systemem wartości. 
Stereotyp psa w języku polskim jest dychotomiczny i niespójny, a nawet wewnętrznie sprzeczny. Składa się z dwóch przeciwnych biegunów: nacechowanego pozytywnie i nacechowanego negatywnie, niekiedy skrajnie. Według Katarzyny Mosiołek można mówić o dwóch stereotypach psa, obu opartych na przekonaniu, że pies jest gorszy od człowieka, co wynika $z$ antropocentrycznego postrzegania świata. Pierwszy z nich - pozytywny, nacechowany jest litością, a jego centrum stanowi informacja o stosunku psa do człowieka (wierność, posłuszeństwo), natomiast drugi - negatywny z odcieniem pogardliwym, ma za punkt centralny stosunek człowieka do psa (złe traktowania, bicie, wyganianie z domu) (Mosiołek 1992, 301-302). Trzeba dodać, że pozytywna część obrazu psa, oparta na kojarzeniu go z wiernością, posłuszeństwem, oddaniem człowiekowi, czyli cechach wynikających z natury psa i zaobserwowanych przez ludzi, jest znacznie uboższa od części negatywnej. Ta druga opiera się nie tylko na właściwościach obiektu, ale też na wielu związanych z psem uprzedzeniach i obciążeniach kulturowych, jak przypisywanie mu bezwstydności, nieczystości, kłamstwa, i znajduje w języku dużo więcej odzwierciedleń w postaci frazeologizmów, przysłów i powiedzeń.

Stereotyp, jako ugruntowany językowo-kulturowy obraz obiektu, jest $\mathrm{z}$ definicji stały - gr. stereós 'twardy, stężały'. Stały w wypadku stereotypu znaczy niewątpliwie, że poddaje się zmianom wyjątkowo powoli i opornie. Jednak musi im podlegać, bo ewolucji ulega grunt, z którego się wywodzi - zarówno język, jak i kultura. Właśnie zmiany w stereotypie psa są przedmiotem mojego zainteresowania. Prześledzenie niektórych elementów tworzących obraz psa w polszczyźnie pozwoli zobaczyć, na ile jest on rzeczywiście stały, a na ile ulega ewolucji w miarę rozwoju wiedzy, zmian kulturowych i obyczajowych.

Stereotypy zwierzęce mają antropocentryczny charakter - ujawnia się w nich stosunek człowieka do zwierząt, który, jak się wydaje, na przestrzeni dziejów uległ pewnej przemianie. Musi ona być widoczna w stereotypie psa - zwierzęcia związanego z człowiekiem najdłużej i, przynajmniej współcześnie, chyba najbliżej. Pies, niegdyś uważany za najmniej przydatne zwierzę w gospodarstwie, bo nieprzynoszące realnego zysku, dziś stał się najlepszym przyjacielem człowieka. Wpływ na to ma rozwój kultury, zmiany, jakie dokonały się w obyczajach, a przede wszystkim zmiana stosunku człowieka do otaczającej go przyrody, uznanie jej za wartość, której nie wolno poskramiać, jak dawniej, tylko trzeba chronić. $W$ takim rozumieniu przyrody zawiera się uznanie elementarnego szacunku dla zwierząt jako istot żywych i czujących.

$\mathrm{Z}$ czym kojarzy nam się dzisiaj pies? Oto kilka wypowiedzi zaczerpniętych z Internetu: Pies to najlepszy przyjaciel człowieka. Zgadzam się; pies naj- 
lepszy tak!!! człowiek prędzej cię zdradzi niż pies bo pies nigdy!!! pies jest lojalny $i$ wierny; To jest tylko dowodem, że zwierzęta mają dusze, a nie instynkt...... Co do pytania...... Psy sq wierne, bo tak jak ludzie posiadaja pewna osobowość, składająca się z wielu cech charakteru, w tym największej, najbardziej dominującej jaka jest wierność...; Psy, to istoty czujące i wierne do końca. Tylko z właścicielami bywa różnie ${ }^{1}$.

Niewątpliwie dzisiaj nasza kultura uważa psa za zwierzę do towarzystwa, wymaga od nas należnego zwierzęciu szacunku i właściwego traktowania, wyznacza też psu doniosłą rolę - rolę naszego przyjaciela. Wiele wieków po udomowieniu i związaniu się z człowiekiem pies został wreszcie doceniony. Dziś w skojarzeniach na plan pierwszy wysuwa się jako podstawowa cecha psa jego wierność wobec człowieka, jest ona odpowiednio ceniona, uznawana za wartość, nawet doczekała się pomników ${ }^{2}$.

W języku mamy także dowód tej konotacji - frazeologizm wierny jak pies. W Słowniku języka polskiego Doroszewskiego pośród licznych wyrażeń pod hasłem pies na pierwszym miejscu znajdujemy wierny jak pies 'bardzo wierny, bezwzględnie oddany, przywiązany'. Cytat pokazuje wyraźnie pozytywne nacechowanie: Pracowita jak mrówka, wierna jak pies, trzymała się dłuższy czas już przy domu Linowskich ... (SJPD). Zestawienie cech ujętych $\mathrm{w}$ zapisie - pracowita $i$ wierna potęguje pozytywne nacechowanie. Potwierdza tym samym, że element stereotypu psa odwołujący się do jego wierności jest jednoznacznie pozytywny. Pod hasłem $p s i$ w tym samym słowniku znajdujemy psie przywiązanie, psia wierność: Ale bo to poczciwy chłopak ... Z jakich on mnie sytuacji nie wyprowadza ... ile daje mi dowodów nieledwie psiego przywiązania! (SJPD). Tu psie przywiązanie zestawione jest $\mathrm{z}$ jednoznaczną oceną bohatera - poczciwy chłopak, widać zatem, że konotowana w stereotypie cecha psa traktowana jest jako ceniona wartość. W słowniku Dunaja wierny jak pies ma objaśnienie 'bezwzględnie lojalny, oddany, bardzo wierny’: Był wierny jak pies wobec swojego dowódcy (SWJPDun).

1 Zachowano pisownię oryginalną z forum internetowego: wątek Pies to najlepszy przyjaciel człowieka czy nie? (http://forum.photoblog.pl/index/topic/tid/2302).

${ }^{2}$ Pomnik psa Dżoka znajduje się na bulwarach wiślanych w Krakowie. Pomnik autorstwa prof. Bronisława Chromego został odsłonięty 26 maja 2001 roku. Przedstawia psa wyciągającego w kierunku widza lewą łapę. Pies znajduje się wewnątrz rozłożonych ludzkich dłoni. W założeniu symbolizuje psią wierność i ogólniej - więź zwierzęcia z człowiekiem. Napis na pomniku (w językach polskim i angielskim) głosi: Pies Dżok. Najwierniejszyz wiernych, symbol psiej wierności. Przez rok /1990-1991/ oczekiwał na Rondzie Grunwaldzkim na swojego Pana, który w tym miejscu zmart. 
Dziś psia wierność wydaje się cechą tak oczywistą i zarazem tak ugruntowaną w świadomości ludzi, a także w języku, że trochę dziwi fakt, iż Słownik staropolski odwołuje się tylko do negatywnej części psiego stereotypu, o wierności psa ani słowem nie wspominając. Pierwsze poświadczenie kojarzenia wierności z psem przynosi XVI wiek, np. Aleć pies człowieku wierny / Acż go bijefz wżdyć pokorny (SPXVI). SPXVI podaje wyrażenie wierny być jako ten pies, pies wierny, jednak zamieszcza przy nim tylko jeden cytat, który takiego sformuło-

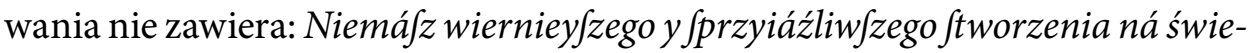
ćie cżłowieku iáko pies (SPXVI). Powyższe konteksty dotyczą zwierząt w sensie dosłownym, są dowodem na obserwację psiego zachowania. Nie ma natomiast żadnego cytatu o charakterze metaforycznym, ze znaczeniem odniesionym do człowieka, takiego, które mogłoby świadczyć o stałości powiązania wierności i psa jako powszechnie kojarzonego nosiciela takiej cechy. Ponadto pośród wielu związanych z psem frazeologizmów odnoszący się do wierności umieszczony jest w haśle słownikowym na dalekim miejscu, blisko końca. Wskazuje to na jego słabe jeszcze zakorzenienie w języku, a tym samym na nieobecność pozytywnej strony współczesnego psiego stereotypu w świadomości szesnastowiecznych użytkowników języka. Linde podaje ten sam cytat, ale bez wskazania na połączenie wierny jak pies, chociaż cytowane przez niego wyrażenie: Byś swemu psu i nogę uciąt, przecię on za toba pójdzie dość wyraźnie sugeruje kojarzenie psa $\mathrm{z}$ wiernością i przywiązaniem. Nie ma też żadnego odwołania do psiej wierności w słowniku Paska i Kochanowskiego, dopiero u Mickiewicza pies otrzymał epitet wierny: ... tyż to psie nasz wierny; Tu go pies wierny znalazł; $U$ wrót pies wierny zawyje (SMick) i, jak pokazują cytaty, pozytywne nacechowanie. Ale nie zawsze: Po wiernych psów zgonie / Większy płacz niż tu po Napoleonie (SMick) ma wydźwięk raczej negatywny, ironiczny. Nieco inne nacechowanie ma zapis: Psy darly swoich Panow. Jeden pies zachowat / Wierność panu swojemu (SMick). Kontekst wydaje się wskazywać na to, że z jednej strony w czasach Mickiewicza psu przypisuje się już cechę wierności, z drugiej jednak pobrzmiewa tu inny aspekt stereotypu, zawierający się w określeniach zły jak pies, wściekły pies. W Słowniku warszawskim figuruje zapis Niewolnicy jak psy im stużli z objaśnieniem 'wiernie' (SW). Trudno określić, jakie nacechowanie ma fraza stużyć jak psy w zestawieniu z niewolnikami - może znaczyć, że to oddani, wierni z natury, jak pies niewolnicy, ale też pozytywne nacechowanie może być umniejszone przez konotację „służyli jak psy”, czyli wiernie z przymusu, skoro to niewolnicy. Nie wydaje się, by można było uznać ten kontekst za przykład jednoznacznego, pozytywnego nacechowania - zatem pies jest tu przykładem wierności, ale nie jest jasne, czy ta wierność wyraża wartość, czy jest oceniana nieco pogardliwie. 
Czyżby aż do czasów Lindego nie zauważano nadzwyczajnej skłonności psa do przywiązywania się do człowieka z bezwzględną wiernością? Wydaje się, że przyczyna nieobecności frazy wierny jak pies tkwi raczej w dawnym znaczeniu przymiotnika wierny.

Według Słstp wierny to: 1. 'prawdziwy, niefałszywy', 2. 'wierzący', 3. 'gorliwy, pilny', 4. 'godny zaufania, rzetelny, niezawodny, dochowujący wiary', 5. 'szczery prawdomówny', 6. 'zgodny z prawem'. Raz tylko, w czwartym znaczeniu, pojawia się zestawienie, ze współczesnego punktu widzenia oczywiste, przymiotnika wierny z rzeczownikiem przyjaciel: Szeczbych wyernym przygyaczelem była (Słstp z XV w.). To znaczenie i zestawienie z przyjacielem można chyba uznać za punkt wyjścia współczesnego wyrażenia wierny jak pies. Jednak zmiana znaczenia przymiotnika wierny przebiegała powoli - $\mathrm{u}$ Lindego wierny to 'wierzący w co, wiarę mający', 'niezdradziecki, wierności dochowujący, wiary danej dotrzymujący' - zatem znaczenie odnoszące się do przyjaźni i oddania jeszcze znajduje się na drugim miejscu i z kontekstów wynika, że nie osiągnęło dominacji. U Doroszewskiego wierny znaczy już zupełnie co innego 'dochowujący wiary komu, czemu, nie odstępujący, nie zdradzający, przywiązany do kogo, służący $\mathrm{z}$ oddaniem, zaufany, pewny', a więc koresponduje tylko z czwartym znaczeniem staropolskim - 'godny zaufania, rzetelny, niezawodny, dochowujący wiary’. Zaistnienie w świadomości zbiorowej i w języku skojarzenia psa z określeniem wierny jest dość późne, ale nie musi wynikać z niezdolności do obserwacji psich cech czy braku szacunku do zwierząt, wynika raczej z innego rozumienia przymiotnika wierny, długi czas zarezerwowanego dla sfery wiary i idei.

Także w słownikach gwarowych języka polskiego nawiązanie do psiej wierności pojawia się nadzwyczaj rzadko - pośród bardzo licznych wyrażeń ze słowem pies porównanie wierny jak pies występuje jedynie w gwarze Domaniewka (SzDom) oraz wśród przysłów i powiedzeń ludowych ze Śląska Cieszyńskiego (Ondr). U Karłowicza przyznanie psu cechy wierności poświadcza pośrednio wprawdzie, ale dość dobitnie - imię psa Wiernuś (Karł, powiat ropczycki). Słowo wiernuś jako apelatyw notuje Dejna z objaśnieniem 'ktoś bardzo wierny' (DKielŁ). W słowniku gwary kaszubskiej nie ma frazy wierny jak pies, ale Sychta przytacza ludową nazwę Gwiazdy Polarnej - Panajezusow Pies i objaśniającą ją, wzruszającą anegdotę, która świadczy o dostrzeganiu przez lud wiejski wierności jako cechy charakterystycznej psa: $Z$ boku Wielkiego Wozu biegnie Panajezusow Pies, którego podarowali mu pasterze, gdy przybyli z pokłonem do Betlejem. Przez dtugie lata bawit się nim mały Jezus. Ten sam pies towarzyszył mu potem w wędrówkach po świecie, broniąc go przed zbójcami w lasach. Gdy wreszcie zdecht, przeniósł go Pan Jezus, któremu tak wiernie służyt, na niebo, skąd, jako Gwiazda Polarna, pokazuje wszystkim podróżującym drogę (Sychta). 
O ile brak frazeologizmu wierny jak pies w staropolszczyźnie i później jeszcze był nieco zaskakujący, o tyle znacznie bardziej ze współczesną podstawową konotacją psa nie zgadza się skojarzenie z niewiernością. Warto jednak przypomnieć, że chodzi o staropolskie i szesnastowieczne rozumienie przymiotnika niewierny: 1. 'taki, który nie wierzy w prawdziwego Boga lub Chrystusa, nie dochowujący wiary Bogu, bezbożny', 2. 'nie dochowujący wierności, wiarołomny, podstępny, zdradziecki, taki, co do którego nie ma się pewności, zaufania' (SPXVI). Opozycja wierny : niewierny w XV i XVI wieku wyraźnie odnosi się do wiary w Boga, tej słusznej i powszechnie uznawanej, lub jej braku, czyli pogaństwa. Z pogaństwem właśnie kojarzony jest w staropolszczyźnie pies. $\mathrm{W}$ tych kontekstach pies jest już obelgą, zresztą $\mathrm{w}$ takiej funkcji występuje często, ale związek tej obelgi z pogaństwem, zwłaszcza ze znienawidzonymi Turkami i Tatarami, rzuca się w oczy. W XVI wieku znajdujemy takie poświadczenia u Kochanowskiego: Córy szlácheckié (żal sye mocny Boże) Psóm Bisurmánskim brzydkié śćiela łoże (SPXVI), później podaje je Linde z XVII wieku - Ty psie pogański!; Psom bisurmańskim córki nasze służą, powtarzają się jeszcze u Mickiewicza: O psie pogański! (SMick). Pies jako obelga pasuje do wszystkiego, co znienawidzone, a zwłaszcza do wrogów Polski, widać to na przykład u Mickiewicza przy objaśnianiu nazwy Psie Pole: Zdawna psami Niemców przez wzgardę nazywano. I Bandkie mniemał, $\dot{z} e$ Psiepole (...) dla tego tak nazwano, iż tam wiele Niemców (psów) wymarło (SMick).

Powyższe cytaty odnoszą się już do drugiej strony stereotypu psa - nacechowanej negatywnie, związanej z nienawistnym i pogardliwym postrzeganiem tego zwierzęcia przez człowieka. Należy tu przypomnieć, że motywacja frazeologizmów związanych z psem może być różna. Katarzyna MosiołekKłosińska $(1995,26,29)$ wymienia kilka możliwych motywacji takich związków. Może ona być oparta na obserwacji stosunku psa do ludzi bądź ludzi do psa, ale liczna grupa frazeologizmów ma za podstawę subiektywne sądy człowieka o tym zwierzęciu. Tu najmocniej są odzwierciedlone asocjacje kulturowe, przekonanie o nieczystości psa, co owocuje jego negatywnym obrazem, negatywną stroną jego stereotypu. W takie widzenie wpisuje się drugie $\mathrm{z}$ najpopularniejszych skojarzeń z psem - łże jak pies. W odczuciu człowieka współczesnego, który traktuje psa jak przyjaciela, jest też kulturowo zobowiązany do poszanowania zwierząt, zwykle zresztą z pełnym przekonaniem, przypisywanie psu kłamstwa jawi się jako wielka niesprawiedliwość, gdyż przeczy to wiedzy i doświadczeniu. Ale siła stereotypu powoduje, że, jeśli nawet rzadko i z mieszanymi uczuciami, Polacy wciąż takiej frazy używają, a przynajmniej ją rozumieją. 
W słowniku Doroszewskiego pośród bardzo licznych wyrażeń z wyrazem pies tżeć (zełżeć) jak pies 'bezwstydnie, bezczelnie (s)kłamać' umieszczone jest pod koniec ciągu potocznych fraz: Jeżeli szlachcic szlachcica nazwie bękartem, zapłaci mu sześćdziesiąt grzywien [...] a jeżeli jego matkę nierzadnica, wtedy prócz sześćdziesięciu grzywien musi odwołać przez wyrzeczenie słów „zełgałem jakpies" (SJPD). Z całą pewnością fraza ta jest historycznie dobrze ugruntowana w języku polskim, co pokazuje także przy toczony kontekst - we współczesnym słowniku jest on jednak historyczny. Chociaż dobrze rozumiane, wyrażenie łże jak pies jest dziś rzadko używane, zwłaszcza w oficjalnych wypowiedziach występuje sporadycznie. Jednak nie wynika to chyba bezpośrednio z weryfikacji stereotypu na podstawie obiektywnych obserwacji. Wydaje się, że powodem tego, poza archaicznym nieco brzmieniem zwrotu łże jak pies, jest odczuwanie go jako bardzo obelżywego i unikanie go z grzeczności.

W języku polskim od XV wieku obecne jest łgać, tygać, kłamać, szczekać jako pies 'kłamać, mówić nieprawdę': ...lygalbych jako pyes contra suam serenitatem; Clamacze, chlopy, yako psy!; Tho, czoszm mowyl, lgalem iako pyes... (Słstp). Liczba poświadczeń i pochodzenie z różnych źródeł świadczą o tym, że w staropolszczyźnie używano tej frazy często. Podobnie było w XVI wieku: A odwoływáiąc [pomówienie] ma mówić: iż com mówił / łgałem iáko pies (SPXVI) - i później: On jak pies kłamał (Linde). W XVII wieku samo słowo pies stanowi już obelgę, szczególnie dla kłamcy. Słownik Paska podaje: pies przen. 'o kłamliwych podłych ludziach': Pewnie tak wielkiego stada nie upasiesz ... chyba zebyś się na tych psow spuszczał których wedle siebie masz dostatkiem; Obrocit się krol do Podkomorzego koronnego y rzekł pies to mowił (SPas). Słownik warszawski przytacza wyrażenie łgat to jak pies, a także frazeologizm psy na kim wieszać, czyli 'obmawiać kogo', a wileński - skłamał jak pies. Wieszać na kimś psy w znaczeniu 'obmawiać, oczerniać, odsądzać kogoś od czci i wiary' (SJPSz) jest używane do dziś. Dialekty także potwierdzają stereotypowy związek psa z kłamstwem, np. u Karłowicza znajdujemy frazę łże kiej pies i szczeka kiej pies (SGPKarł), ale ta druga ma nieco złagodzone znaczenie 'dużo gada'.

Ugruntowane, stereotypowe połączenie psa z kłamstwem przeciw komuś, z oszczerstwem przenosi się także na czasownik szczekać ${ }^{3}$ - jak widać wyżej, w Słstp umieszczony w ciągu z łgać, kłamać. Słstp notuje szczekać w przenośnym znaczeniu 'kłamać, obmawiać: Csom vczynyl Iachnye, thom vczynyl za

${ }^{3}$ Skojarzenie to daje się zauważyć już we wczesnym średniowieczu w kręgu kultury chrześcijańskiej - św. Augustyn uważał psa za symbol heretyka i pisał: „A ty heretyku przeciwko temu szczekasz! Stąd też słusznie powiedziano w owym mieście, co zapisano w Apokalipsie: Psy za drzwi” (cyt. za: Kobielus 2002, 259). 
gey począthkyem, kyedi my rzekla: Scekas (Słstp). Kontekst, dotyczący sprawy sądowej o krzywdę, która została uczyniona Jachnie, pokazuje, że postawienie komuś zarzutu szczekania, czyli kłamstwa, kłamliwego obmawiania, uważane było za bardzo obraźliwe, skoro sprawca tłumaczy się w odpowiedzi na ten ciężki zarzut tym, że uczynił krzywdę niejako z winy pokrzywdzonej. $\mathrm{W}$ niemal identycznym kontekście pojawia się w Słstp wyrażenie (po)dawać szczekarze 'nazywać kłamcą': Cszo[m] vczinil Wszeborowi, tom vczinil za iego poczøtk[em], kedi mi podawa[ł] sczekarz[e]; Czsom vczinil Mikolagoui tho za gego poczanthkem, kedi mi daval szczekarze (Słstp). Widać zatem, że szczekanie było oceniane w kategoriach moralnych bardzo negatywnie.

W słowniku Lindego pod hasłem szczekać znajduje się przenośne znaczenie: szczekać na kogo, o kim 'potwarzać, kłamliwie obgadywać': Śmieja prawdzie uwłoczyć i na jawność szczekać; Gniewosz musiał na sejmie pod ława jawnie głosem wielkim jak pies szczekać, a odwolywać i wyznawać, iż łgał i szczekat niecnotliwie, jako pies, o cnotliwej królowej (Linde). Kontekst pokazuje obyczajowe znaczenie derywowanego czasownika odszczekać, odszczekiwać. Historia bohatera przy toczonego zapisu pojawiła się już wcześniej - jest cytowana w SPXVI pod hasłem odszczekawać ' $\mathrm{z}$ wyroku odwołać obelgę wszedłszy pod lawę: A ták Gniewojz był o to pozwan ná Seym do Wiślice / który gdy tego dowieść nie mogł co mowit / z dekretu Krolewfkiego pod łáwa to odwoływác / ábo iáko pofpolićie mowia iáko pies odfzcżekáwać muśiat przed w/zyftkimi / ku fwej wiecznej háńbie (SPXVI). SPXVI podaje jeszcze znaczenie 'niegrzecznie odpowiadać, powtórzone u Lindego. W Słowniku warszawskim znajdujemy szczeknać, szczekać, szczekotać przen. 'łgać, kłamać, zmyślać niegodziwie, gębować, pyskować, obgadywać, obmawiać, szkalować, czernić, wygadywać: Niech na mnie szczeka; Szczekasz przeciwko niemu, zazdroszcząc mu tego kupna (SW). U Doroszewskiego także potwierdza się podobne znaczenie: szczekać posp. 'obmawiać, oczerniać kogo, szkalować, łgać, kłamać, zmyślać: Ludzie pyskowali na niego. A niech tam! Mało to szczekających; Szczekamy na nich, wyśmiewamy, a sami w gruncie rzeczy naśladujemy ich, i to jak nieudolnie; Czy może być większa podłość, jak za pieniądze szczekać przed kratami, przeciwko takiemu, przeciw któremu nic złego się nie czuje? (SJPD). W języku ludowym szczekać znaczy 'łgać, kłamać' - u Karłowicza, u Sychty 'zmyślać, kłamać, szkalować' (Sychta). Na Kaszubach używane jest porównanie szczekać jak pies z objaśnieniem 'o człowieku pyskatym' (Sychta), co oznacza przesunięcie znaczenia i jego złagodzenie w kategoriach oceny moralnej. Samo szczekać ma także znaczenie 'głośno mówić, wrzeszczeć' (Sychta). Niekiedy w dialektach szczekać używane jest w szczególnych sytuacjach - na przykład w okolicach Malborka w znaczeniu 'przemawiać przez radio - o znienawi- 
dzonym polityku’: Jak Hitler abo Gebels szczekał, my zawdi radio zamknęli (GórnMalb). Jednoznacznie negatywną ocenę moralną szczekania potęguje tu odniesienie do postaci, których przemówienie tak określono, natomiast we wcześniejszych kontekstach jest ona podkreślona przez zestawienie z takimi cechami, jak zazdrość czy podłość.

Taka ocena wyraża się także w licznych derywatach od czasownika szczekać. Ich duża liczba, trwanie od dawna w języku i obecność w wielu dialektach świadczą o sile negatywnej strony stereotypu psa, o nierozerwalności powiązania psa $\mathrm{z}$ kłamstwem. I tak już w XV wieku pojawia się szczekacz 'kłamca': Wolwram ... palam cognoverat Albertum de Barklino vlg. sczeczcza (pro sczecacza?), dicens se probaturum ... (Słstp) i szczekarka 'kłamczucha': Dehonestavit (sc. Jacob Margaretham) [...] asserens ipsam meretricem veterem mendosam al. sczekarka (Słstp). Szczekacz jest dobrze poświadczony w słownikach ogólnopolskich, np. u Reczka jako 'obmówca, oszczerca, potwarca': Niźliby mieli naśladować szczekacza i bluźnika (Recz), u Lindego: Łapacza a wykrętnika szczekaczem zowia, podobnie w Słowniku warszawskim, natomiast $\mathrm{w}$ niektórych dialektach ma nieco zmodyfikowane, ale wciąż zbliżone znaczenie 'pyskacz' (DKielŁ). W znaczeniu 'kłamca, oszczerca' występuje także szczekarz i szczekun. Natomiast osobę pyskatą i krzykliwą określa się mianem szczekot, zarówno we współczesnym języku polskim (SW, SJPD), jak i w różnych dialektach (Karł, Sychta), na Kaszubach to samo oznacza szczekuła, czyli 'człowiek pyskaty i kłótliwy' (Sychta). Dialekt kaszubski dysponuje także żeńskimi derywatami od szczekać, są one nacechowane negatywnie, ale dotyczą raczej skłonności do plotek i kłótni niż kłamstwa czy oszczerstwa, np. szczekaczka, szczekotka, szczekarnica, szczekalnica, szczekta, szczeknica, szczeka 'kobieta gadatliwa, kłótliwa, pyskata' (Sychta). Dwa z tych derywatów warto zauważyć $\mathrm{z}$ racji wyspecjalizowanego znaczenia. Szczeka w ogólnopolskim znaczy 'obszczekiwanie, obmowa, potwarz, kalumnia, oszczerstwo': Cudza szczekę dalej wlekę (SW), czyli kontynuuje znaczenie słowa szczekanie notowanego u Reczka 'obmowa, oszczerstwo, potwarzanie' (Recz), natomiast szczekaczka poza podstawowym znaczeniem zyskała dodatkowe - 'megafon uliczny w czasie okupacji' (SJPD), co świadczy o skrajnie negatywnym ładunku emocjonalnym łączonym $\mathrm{z}$ tym słowem.

Trzecim elementem stereotypu psa, negatywnym, ale nie tak skrajnie ocenianym w kategoriach moralnych, jest „bylejakość”, bycie niczym, brak wartości. Znajduje to wyraz w wielu wyrażeniach $\mathrm{z}$ wyrazem pies lub psi czy pieski, a za podstawę ma chyba powszechne uznawanie psa za zwierzę domowe, z którego pożytek jest najmniejszy w gospodarstwie, przynajmniej w sensie materialnym. 
Współcześnie ten element stereotypu psa jest obecny przede wszystkim w powszechnie używanych określeniach psia pogoda lub pogoda pod psem oraz kupić (sprzedać) coś za psie pieniądze, psi grosz, a także pieskie życie.

W słowniku Doroszewskiego znajdujemy przymiotnik psi i określenie pod psem. Z kontekstów wynika, że mają ogólne znaczenie przenośne 'marny, kiepski, niekorzystny', np. psi czas, psia pogoda 'zła, deszczowa pogoda': Do Zakopanego dojechałem dobrze, ale trafitem na psi czas. Bywało po 4 stopnie $w$ dzień i trzeba było palić w piecach (SJPD). Pod psem odnosi się także do dóbr materialnych w kiepskim stanie, niskiej wartości: Wszystko się niebawem na powrót psuło, czworaki były, po prostu mówiąc, pod psem (SJPD). Skorupka objaśnia pod psem, pod zdechlym psem jako 'niżej wszelkiej krytyki, w złym stanie' i wymienia ewentualne obiekty: obiady, robota, pogoda, zdrowie pod psem; czuć się pod psem 'czuć się niedobrze' (FSkor). Podobne znaczenie ma fraza za psi grosz, za psie pieniądze 'bardzo tanio, za bezcen', czyli po prostu za nic: Sprzedać koni już nie było czasu, zreszta za psi grosz szły (SJPD). Znaczenie bardzo niskiej wartości widać także w określeniu psi los, psie życie 'nędzne, podłe życie, marny los': Pluję na psie życie, jakie wiedziemy od tygodnia (SJPD). Jest ono ugruntowane także w przymiotniku pieski 'nędzny, zły, marny': Pieskie szczęście mamy, co chłopaki? Już drugi raz alarm po obiedzie; Niech ten, co miał pieskie życie, ma i pieski grób (SJPD). To samo znaczenie niesie potoczny przysłówek piesko 'źle, ciężko, trudno, nędznie': W pierwszych latach wojny było piesko (SJPD).

Przymiotniki psi i pieski są znane w języku polskim od wieków. W staropolszczyźnie $p s i$, oprócz podstawowego znaczenia 'związany z psem', ma także znaczenie 'zły, dokuczliwy, szkodliwy', jednak Słstp podaje tylko jeden kontekst dotyczący psiej muchy: Poslal w ne psø muchø (coenomyiam) y iadla ie (Słstp). W XVI wieku pojawia się przymiotnik pieski, który, przy znaczeniu 'taki jak pies', pełnił funkcję obraźliwego epitetu: [Pigmeowie] Obycżáiem Tátárów pieskich też działaja / co mocż / y kréw i mleko kobyle piiaia (SPXVI). W tym kontekście taki jak pies znaczy znienawidzony i pogardzany. Znaczenie 'lichy, marny, bezwartościowy' potwierdzone jest w przytaczanych przez Lindego frazach: psi obiad, psia strawa 'potrawa podła, zła'. W Słowniku wileńskim pod hasłem psi znajduje się objaśnienie 'wart psa, złośliwy, bezwstydny' z przykładami psie życie, psie rzemiosło, psia strawa, psia bezwstydność 4 . Podobne znaczenia poda-

${ }^{4} \mathrm{Na}$ temat stereotypowego skojarzenia psa z bezwstydnością, cudzołóstwem i brakiem moralności pisałam w artykule Jak wieszamy psy na ... psie - obraz psa w językach zachodniosłowiańskich $i$ ich dialektach $\mathrm{w}$ tomie Europa Stowian (w druku). 
je Słownik warszawski z cytatami, np.: kupić co za psie pieniądze, psia zapłata, także w odniesieniu do szczęścia: ja mam takie szczęście psie do ludzi, że mnie nikt poczciwego nie dał słowa (SW). Przymiotnik pieski w SW ma objaśnienie 'zły pod jakimkolwiek względem, nieznośny, piekielny, niegodziwy, złośliwy, nędzny, bezwstydny, obrzydliwy, przeklęty, lichy' - widać tu bardzo silne nacechowanie negatywne, jednak odnosi się ono raczej do aspektów moralnych, jedynie znaczenia 'nędzny, lichy' dotyczą niskiej wartości, małości.

Podobne znaczenie mają przymiotniki psi i pieski w dialektach, np. pieski 'zły, niedobry, lichy, kiepski, niewygodny' występuje w zestawieniach pieska pogoda, pieska robota; psi 'kiepski, lichy' (SzDom, DKielŁ). Przymiotnik psi tworzy zestawienia z nazwami roślin i owoców, oznaczające rośliny niezdatne dla człowieka, czyli bezwartościowe, lub wręcz trujące, np. psi grzyb, psia jagoda (StWar). Bywają one też nazywane rzeczownikami tworzonymi od podstawy pies, np. psiorka 'suchy, niewyrośnięty owoc przedwcześnie spadający z drzewa; w ogóle lichy owoc' (SzDom), czy psiara 'muchomor' (DKielŁ).

$\mathrm{U}$ Lindego występuje wyrażenie $z a$ psa to stoi $\mathrm{w}$ znaczeniu 'jest nic nie warte': Łazarz ubogi za psa u bogacza stoi; Za psa tytuł u mnie, kiedy pustki w kalecie. To samo znaczenie podaje SW: Dziś za psa sumienie, sława, wiara i cnota. Zapis Złej szkapie i rząd złocisty nic nie pomaga, jeśli żadnej cnoty z przyrodzenia nie ma, ale po staremu psem będzie (SW) pokazuje, że być psem oznacza 'być istotą marną, czymś bezwartościowym'.

$\mathrm{Z}$ konotacją braku wartości, bycia niczym wiąże się powiedzenie zejść na psy o znaczeniu 'stracić siły, zbiednieć, zubożeć, podupaść', 'wykoleić się moralnie' (SJPSz). Znaczenie ogólne 'stracić wartość' dotyczy tu dwóch różnych sfer życia - materialnej czy fizycznej, gdzie oznacza utratę sił witalnych lub dóbr materialnych, i duchowej, gdzie w ten sposób określa się degradację moralną. Pierwszy aspekt - 'zubożeć, zmarnieć' pokazuje kontekst: Zbiedniały, zeszły na psy [...] jak żebraczki stoja pod kuchnia mitosierdzia (SJPD), natomiast wykolejenie, upadek moralny oddaje zapis: Źle skończy ... gorzej niż jej matka ... sto razy ... Pan zobaczy ... na psy zejdzie (SJPD). Współczesne, nowe użycia określenia zejść na psy znajdujemy w słowniku Dunaja: Teatr telewizji schodzi na psy; Zszedł na psy, odkąd stracił pracę i zaczą pić (SWJPDun). Taka stereotypowa, związana $\mathrm{z}$ psem utrata wartości w różnym rozumieniu jest silnie ugruntowana w polszczyźnie. U Lindego występuje wyrażenie wszystko za psa pójdzie 'w niwecz, niszczeje, nikczemnieje'. Od doby średniopolskiej wyrażana była czasownikami utworzonymi od podstawy pies. W Małym słowniku zaginionej polszczyzny figuruje czasownik psieć 'stawać się gorszym, schodzić na psy' (MSZP), natomiast w Podręcznym słowniku dawnej polszczyzny znajdujemy psieć 'marnieć' i formy prefigowane zepsić się 'zepsuć się, zgorszyć się’: Sio- 
stry jego obcowaniem tym się zepsiły (Recz) i zepsieć 'zejść na psy, znędznieć, znikczemnieć: Świat na koniec wszytek tak zepsieje (Recz). U Lindego wymieniono kilka form: psieć, zepsieć, zpiesieć, psić się ' psem się stać, na psa się godzić, kundleć' - konteksty pokazują znaczenie 'marnieć, tracić siłę, sprawność, tracić moralność, poczucie obowiązku, tracić wartość’: Najpierw na nogi psieje każdy stary; Od próżnowania psieje i wczasów w obozach szuka żotnierz; Gdy sokot zpiesieje, bije go i wrona; Stuga zły próżnowaniem zepsieje, i jeszcze daleko gorszym, niżeli piérwéj będzie (Linde). Podobne znaczenie niosą konteksty ze Słownika warszawskiego: zepsieć 'zejść na psy, zbiednieć, zdziadzieć, spsieć': Stadnikowi trawy nie dawaj, bo mu zaraz w nogi wstapi i zepsieje. U Doroszewskiego znajdujemy tylko prefigowane formy spsieć z kwalifikatorem rzadki: Ornoch coś spsiał [...] Taki był wielki pan [...] Teraz tylko prosi, żeby mu tysiąc złotych pożyczyć oraz zepsieć: Całe szczęście, że i tacy jak wy sq też, bobyśmy catkiem zepsieli; Może by i nieźle jemu co przeczytać, żeby na Mazura tchną́ lepszym wiatrem poetyckim. Inaczej zepsieje do reszty w Paryżu (SJPD). Przytoczone tu zapisy - od Reja do Mickiewicza - pokazują silnie ugruntowane w języku kojarzenie psa z marnością. Jest ono żywe także w dialektach. W okolicach Krakowa poszła na psy znaczy 'zmarniała, przepadła': A ta druga już na psa posła, bo była carownica (Karł), pod Malborkiem zleźć na psi 'podupaść materialnie' odnosi się tylko do kondycji majątkowej (GMalb). Podobny sens zawiera gwarowe we psia notowane przez Karłowicza o znaczeniu 'na stracenie, na zgubę': Cudzego nie pragnij, swego we psia nie daj (Karł).

Omówione powyżej użycia elementów stereotypu psa w różnych okresach rozwoju polszczyzny pokazują przede wszystkim, że był on obecny w języku już w średniowieczu ${ }^{5}$. Jednak dotyczy to stereotypu negatywnego, który jest starszy i mocniej w języku zakorzeniony. W staro- i średniopolszczyźnie można mówić tylko o negatywnym obrazie psa. Od XV wieku bardzo dobrze jest udokumentowane stereotypowe porównanie łże (kłamie) jak pies. O sile tego połączenia świadczy jego wczesna obecność i duża liczba poświadczeń aż do XIX wieku. Ale nie tylko - połączenie psa z kłamstwem i oszczerstwem ugruntowane jest także przez nadanie czasownikowi szczekać, podstawowo 'wydawać głos właściwy psu', znaczenia przenośnego 'kłamać, łgać', a także

${ }^{5}$ W artykule Jak wieszamy... wykazałam pewne podobieństwa w stereotypach psa w językach zachodniosłowiańskich. Sugerują one wspólne pochodzenie elementów tego stereotypu, a zatem pozwalają przypuszczać, że stereotyp psa, przynajmniej w części, może być znacznie starszy. Jednak postawienie takiej tezy i określenie początków stereotypu psa wymagałoby badań porównawczych we wszystkich językach słowiańskich. Bardzo dawne udomowienie psa wskazywałoby, że i stereotyp może mieć bardzo długą historię. 
przez bogactwo derywatów od niego utworzonych, w takim właśnie znaczeniu, jak szczekacz, szczekta, zawsze nacechowanych negatywnie. Znamienny jest także udokumentowany językowo dawny zwyczaj odszczekiwania kłamstwa, opatrzony odpowiednią formułą i obyczajem. Wydaje się, że współcześnie fraza łże jak pies jest używana rzadziej. Nie można chyba jednak wysnuwać z tego wniosku, że ten element stereotypu psa wychodzi z użycia. Współcześnie rzadziej się tak mówi przede wszystkim dlatego, że zarzucenie komuś kłamstwa w takiej formie byłoby bardzo obraźliwe, zatem zarzut taki formułuje się raczej eufemistycznie. Jednak lże jak pies jest przez użytkowników języka znakomicie rozumiane, a także odczuwane jako określenie obelżywe. To upoważnia chyba do stwierdzenia, że przy pewnym spadku częstotliwości użycia w ostatnim czasie negatywny element stereotypu psa związany z kłamstwem jest w polszczyźnie najstarszy i nadal żywotny. Pokazuje to, że przy językowych stereotypach mamy $w$ istocie do czynienia $\mathrm{z}$ elementem opornym na zmiany. Trzeba dodać, że jego rzadsze stosowanie wskazuje na tendencję do wyjścia $\mathrm{z}$ użycia, któremu sprzyjać będzie racjonalna wiedza współczesnego człowieka, że psy nie kłamią, a także pozytywny stosunek do tych zwierząt, stojący w sprzeczności z negatywną oceną ugruntowaną w języku, jednak będzie to zapewne wymagało jeszcze dłuższego czasu.

Kolejny element negatywnego obrazu psa - jego brak wartości - pojawił się także dość wcześnie, bo w XVI wieku. Używano wówczas czasowników derywowanych od podstawy pies - psieć, spsieć, zepsieć w ogólnym znaczeniu 'utracić wartość' zarówno w sensie kondycji fizycznej i majątkowej, jak i moralnej. Znaczenie to bazuje na stereotypowym przekonaniu, że pies to coś bez wartości. Ujawnia się także w przymiotnikach psi, pieski. Wszystkie te elementy są dość dobrze udokumentowane w języku, choć później niż łże jak pies, bo po dobie staropolskiej, i wciąż obecne. Czasowniki psieć, zepsieć są dziś używane rzadko lub nawet już nieużywane, najnowsze słowniki ich nie notują, ale to zmiana formalna - ich funkcję przejęło wyrażenie schodzić (zejść) na psy, które funkcjonuje $\mathrm{w}$ języku z powodzeniem. Ten element językowego stereotypu psa pojawił się zatem około XVI-XVII wieku i od tej pory jest nieprzerwanie obecny. Uległ jednak pewnym przeobrażeniom formalnym.

Najistotniejszą przemianą w językowym obrazie psa jest na przestrzeni wieków pojawienie się jego pozytywnej strony, czyli odniesienie do psiej wierności, wyrażanej porównaniem wierny jak pies. Tę zmianę można nazwać rewolucyjną ze względu na jej ciężar gatunkowy, gdyż powoduje przeobrażenie jednoznacznie negatywnego wcześniej charakteru tego stereotypu. Skutkuje powstaniem dychotomii, rozdwojenia stereotypu psa na dwa elementy - negatywny i pozytywny. Nie znaczy to, że zmiana ta przebiegała w sposób nagły, jak wszystko w języku 
dokonywała się stopniowo i powoli. Nieznaczny ślad kojarzenia psa z wiernością i oddaniem człowiekowi pojawia się sporadycznie w XVI wieku, jednak związek ten nie jest traktowany jako stały i oczywisty. Takie pojedyncze czy pośrednie dowody istnienia w świadomości związku psa z wiernością, jak przysłowie Byś swemu psu i noge uciąt, przecię on za toba pójdzie, aż do XVIII wieku jedynie zapowiadają powstanie tego elementu stereotypu psa. Częściej fraza wierny jak pies, wierny pies pojawia się dopiero u Mickiewicza. We współczesnych słownikach jest zawsze obecna, a konteksty pokazują, że łączy się z pozytywnym nacechowaniem. Wydaje się, że wśród użytkowników języka pierwsze skojarzenie z psem to właśnie wierny jak pies, gdyż współcześnie można uznać psa za symbol wierności. Tak późne zaistnienie i utrwalenie w języku tego skojarzenia może mieć kilka przyczyn - po pierwsze dawne znaczenie przymiotnika wierny, po drugie niechętny stosunek ludzi do psów jako zwierząt gospodarskich o małej przydatności. Jednak wydaje się, że najpoważniejszą przyczyną jest właśnie stałość stereotypu. Negatywny obraz psa był dawny, ugruntowany i odporny na weryfikację. To ugruntowanie właśnie - w języku i w świadomości jego użytkowników - utrudniało i spowalniało dostrzeżenie i wprowadzenie do językowego stereotypu cechy psa ocenianej jako pozytywna, czyli przeciwna dotychczasowemu obrazowi. Niewątpliwie dziś, dzięki zmianom kulturowym, zmianom w postrzeganiu miejsca psa w otaczającym człowieka świecie, ten pozytywny element stereotypu jest już dobrze umocowany i wydaje się nawet wysuwać na plan pierwszy w obrazie psa.

Opisane powyżej zmiany wskazują, że stereotyp psa, jakkolwiek silnie zakorzeniony $\mathrm{w}$ świadomości i języku, podlegał jednak na przestrzeni wieków zmianom. Przebiegały one dość powoli, ale miały charakter zasadniczego przewartościowania - zmiany $\mathrm{z}$ jednoznacznie negatywnego obrazu w obraz dwoisty - nadal negatywny w większej części, ale bardzo pozytywny w części odnoszącej się do trwałego powiązania psa z wiernością.

\section{Literatura}

A nusiewicz J., 1995, Lingwistyka kulturowa. Zarys problematyki, Wrocław.

Bar t miński J., Pa nasiuk J., 1993, Stereotypy językowe, [w:] Współczesny język polski, red. J. Bartmiński, Wrocław, s. 363-387.

Bart miński J., 1998, Podstawy lingwistycznych badań nad stereotypem - na przykładzie stereotypu matki, [w:] „Język a kultura”, t. 12: Stereotyp jako przedmiot lingwistyki. Teoria, metodologia, analizy empiryczne, red. J. A nusiewicz, J. Bartmiński, Wrocław, s. 61-83.

Kobielu s S., 2002, Bestiarium chrześcijańskie. Zwierzęta w symbolice i interpretacji. Starożytność i średniowiecze, Warszawa. 
Mosiołek K., 1992, Stereotypy psa zawarte w jezzyku polskim, „Poradnik Językowy” IV, s. 301-304. Mosiołek-Kłosińska K., 1995, Motywacja związków frazeologicznych zawierających wyrazy pies i kot, „Etnolingwistyka” 7, s. 21-31.

Panasiuk J., 1998, O zmienności stereotypów, [w:] „Języka a kultura”, t. 12: Stereotyp jako przedmiot lingwistyki. Teoria, metodologia, analizy empiryczne, red. J. A nusiewicz, J. Bartmiński, Wrocław, s. 84-98.

Peisert M., Sus domesticus - zwierzę, którego nazwy używać nie wypada, [w:] „Języka a kultura”, t. 15: Opozycja homo - animal w języku i kulturze, red. A. Dąbrowska, Wrocław, s. 149-155.

\section{Skróty źródeł}

DKielŁ - Dejna K., 1984, Słownictwo ludowe z terenu byłych województw kieleckiego i łódzkiego, RKJ乇 XXX.

FSkor - Skor upka S., 1993 (wyd. 7), Słownik frazeologiczny języka polskiego, Warszawa.

GMalb - Górnowicz H., 1974, Dialekt Malborski, t. II: Słownik, Gdańsk.

Linde - Linde S. B., 1854-1860, Słownik języka polskiego, t. I-VI, Lwów.

MSZP - Wysocka F. (red.), 2003, Mały słownik zaginionej polszczyzny, Kraków.

Recz - Reczek S., 1968, Podręczny stownik dawnej polszczyzny, Wrocław-Warszawa-Kraków.

SGPKarł - Karłowicz J., 1900-1911, Słownik gwar polskich, t. I-VI, Kraków.

SJPD - Doroszewski W. (red.), 1958-1967, Słownik języka polskiego, t. I-XI, Warszawa.

SJPSz - Szymczak M. (red.), 1978-1981, Słownik języka polskiego, t. I-III, Warszawa.

SKoch - Kucała M. (red.), 2003, Słownik polszczyzny Jana Kochanowskiego, t. III, Kraków.

Słstp - Urbańczyk S. (red.), 1953-2002, Słownik staropolski, t. I-XI, Wrocław.

SMick - Górski K., Hrabec S. (red.), 1962-1983, Słownik języka Adama Mickiewicza, Wrocław-Warszawa-Kraków-Gdańsk.

SPas - Koneczna H. (red.), 1973, Słownikjęzyka Jana Chryzostoma Paska, t. II, Wrocław-Warszawa-Kraków.

SPXVI - Mayenowa M. R. (red.), 1966-2004, Słownik polszczyzny XVI wieku, t. I-XXXII, Wrocław.

Sychta - Sychta B., 1967-1976, Słownik gwar kaszubskich na tle kultury ludowej, t. I-VII, Wrocław-Warszawa-Kraków-Gdańsk.

SzDom - Szymczak M., 1962-1967, Słownik gwary Domaniewka w powiecie łęczyckim, t. I-II, Wrocław-Warszawa-Kraków.

SW - Karłowicz J., Kryński A., Niedźwiedzki W. (red.), 1900-1927, Słownik języka polskiego, t. I-VIII, Warszawa.

SWil - Olgerbrandt M. (red.), 1861, Słownik języka polskiego, t. I-II, Wilno.

SWJPDun - Dunaj B. (red.), 1996, Słownik wspótczesnego języka polskiego, Warszawa.

StWar - Steffen W., 1984, Słownik warmiński, Wrocław-Warszawa-Kraków-GdańskŁódź. 


\title{
The Evolution of Dog's View in Polish Language
}

\author{
(Summary)
}

The article presents the evolution of dog's view in Polish language within the centuries - from Old Polish to the present, considering vocabulary dialect.

The components of a dichotomous present stereotype of dog (the two negative ones and one positive) are analyzed in the work. The negative ones seem to belong to the older structure of the language. The example of association with "a lie" - in Polish $ł \dot{z} e$ jak pies - and its metaphorical meaning of the verb, is well - known from the Old Polish and still used, however, less frequent. The phenomenon seems to be similar to the attributing a dog with its small value, as it is documented in the used meanings of adjectives such as: psi / pieski ('dog-ass').

Late testified, but extremely important element of the dog's view, is associating it with dog's fidelity that was expressed in a phrase wierny jak pies - that is focused on being a faithful dog.

This combination of two meanings resulting in its dichotomy, and even its internal contradiction, rejected the negative stereotype of a dog.

Nowadays, due to the cultural changes including our attitude to animals generally, especially domestic ones, its primary association with fidelity seems to be priority. 